ISSN 0122-5383

\title{
BIOGAS PRODUCTION BY ANAEROBIC DIGESTION OF WASTEWATER FROM PALM OIL MILL INDUSTRY
}

\author{
PRODUCCIÓN DE BIOGÁS MEDIANTE DIGESTIÓN ANAEROBIA DE \\ AGUAS RESIDUALES PROVENIENTES DE LA INDUSTRIA PALMERA
}

\author{
Debora-Alcida Nabarlatz ${ }^{1 *}$, Ligia-Patricia Arenas-Beltrán ${ }^{1}$, Diana-Milena Herrera-Soracá \\ and Diana-Andrea Niño-Bonilla ${ }^{1}$ \\ 'Centro de Estudios e Investigaciones Ambientales (CEIAM), Universidad Industrial de Santander, \\ Bucaramanga, Santander, Colombia \\ e-mail: dnabarla@uis.edu.co
}

(Received: Jul. 16, 2012; Accepted: Apr. 15, 2013)

\section{ABSTRACT}

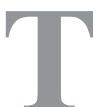

The environmental impact caused by the fossil fuel use encourages society to look for new sources of renewable energy, such as biodiesel. During the last years, palm oil production has dramatically increased in Colombia, since it is the main raw material for biodiesel production. As consequence of the process, palm oil mill effluents with high content of pollutants are released to the environment. Since these effluents have physicochemical characteristics that make them suitable for the production of biogas by anaerobic digestion of residual water, this research evaluates the production of methane using wastewater as substrate from a Colombian palm oil mill. Anaerobic digestion experiments were conducted in batch mode to evaluate the influence of $\mathrm{pH}$ and inoculum to substrate ratio, by using two differents inoculums. It was found that the most suitable inoculum was a mixture of 1:1 v/v urban Wastewater Treatment Plant (WWTP) anaerobic sludge/pig manure at a ratio $2 \mathrm{~g}$ Volatile Solids (VS) inoculum/g VS substrate, which presented the highest accumulated methane production, reaching $2740 \mathrm{~mL}$ methane $\left(0.343 \mathrm{~m}^{3} \mathrm{CH}_{4} / \mathrm{kg} \mathrm{VS}\right)$ without neutralizing $\mathrm{pH}$.

Keywords: Wastewater, Anaerobic digestion, Palm oil, Methane.

How to cite: Nabarlatz, D. A., Arenas-Beltrán, L. P., Herrera-Soracá, D. M. \& Niño-Bonilla, D. A. (2013). Biogas production by anaerobic digestion of wastewater from palm oil mill industry. CT\&F - Ciencia, Tecnología y Futuro, 5(2), 73-84.

*To whom correspondence should be addressed

+V Congreso Internacional de Ciencia y Tecnología de los Biocombustibles, CIBSCOL 2012, Universidad Industrial de Santander, Bucaramanga, Santander, Colombia. 5 - 8 de junio de 2012. 


\section{RESUMEN}

$\mathrm{E}$

I impacto ambiental generado por el uso de combustibles fósiles, incentiva a la sociedad a buscar nuevas fuentes de energía renovables tales como el biodiesel. En Colombia, la materia prima más utilizada para producir biodiesel es el aceite de palma, con lo que su producción ha aumentado drásticamente en los últimos años, generando efluentes con alta carga contaminante para el medio ambiente como consecuencia del proceso. Dado que las características fisicoquímicas de estos efluentes son propicias para la producción de biogas mediante digestión anaerobia, este trabajo evalúa la producción de metano a partir de agua residual de una empresa extractora de aceite de palma colombiana. Se realizaron experimentos de digestión anaerobia en modo batch para evaluar la influencia del pH y la relación inóculo/ sustrato utilizando dos inóculos diferentes. Se encontró que la mezcla $1: 1 \mathrm{v} / \mathrm{v}$ lodo anaerobio de planta de tratamiento de aguas residuales urbanas y estiércol de cerdo usada como inóculo, generó la mayor producción de metano acumulado, alcanzando $2740 \mathrm{~mL}$ de metano $\left(0.343 \mathrm{~m}^{3} \mathrm{CH}_{4} / \mathrm{kg} \mathrm{SV}\right)$, usando una relación de $2 \mathrm{~g}$ SV de inóculo/g SV de sustrato, sin necesidad de neutralizar el pH del sistema.

Palabras clave: Aguas residuales, Digestión anaerobia, Aceite de palma, Metano.

\section{RESUMO}

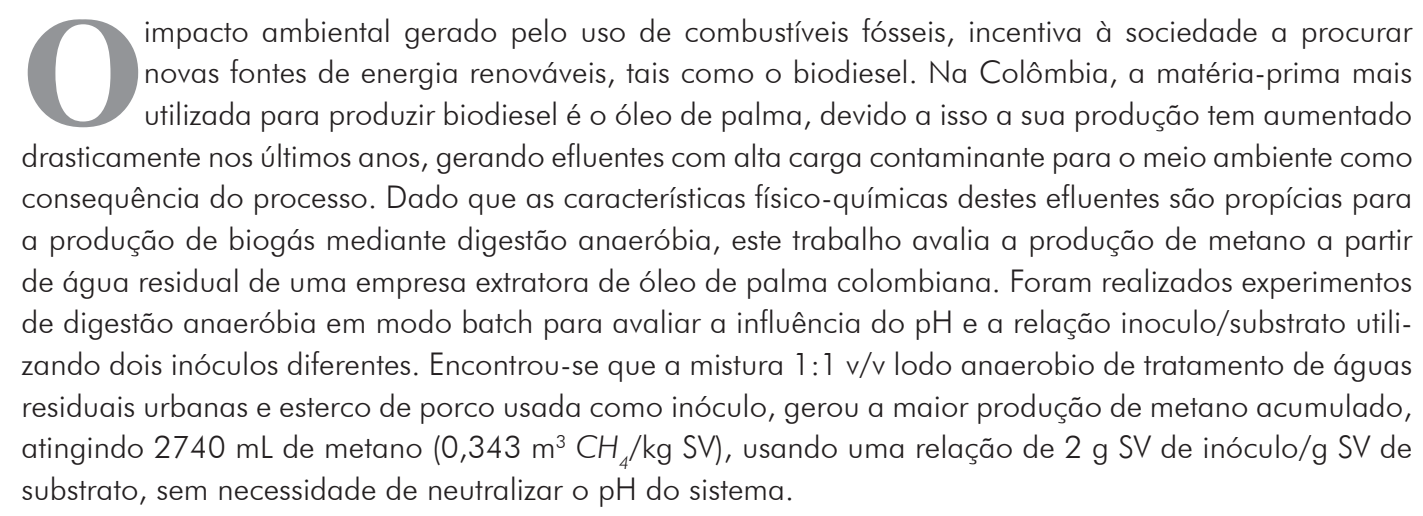

Palavras-chave: Águas residuais, Digestão anaeróbia, Óleo de palma, Metano. 


\section{INTRODUCTION}

The environmental impact generated by the use of fossil fuels motivates the industry and society to search for new sources of renewable energy. Between them, biodiesel has demonstrated to be a biofuel with high potential to partially replace fossil fuels. In tropical and semitropical countries like Colombia, palm oil is used as the main raw material for biodiesel production.

The African palm culture in Colombia starts in 1945 with the United Fruit Company, in a banana cultivation zone in Magdalena state. This culture has extended until reaching 360000 hectare in 2010, making Colombia the first palm oil producer in Latinamerica, and 4th in the world. At present time, the territory designated for palm oil cultivation is distributed in 73 municipalities in 4 productive zones: North, Central, East and West (Lasso \& Ramírez, 2011). Due to this, palm oil industrial sector has a unique opportunity to insert Colombia in a high position in the internal and external markets based on biofuels.

Several research projects are been carried out in the palm oil industry, conducted by Federación Nacional de Cultivadores de Palma de Aceite (Fedepalma), the research association for this industrial sector. Between them, one of the most important is the Clean Development Mechanism Project (CDM) for methane capture, minimization of fossil fuels use and energy cogeneration. This project, approved in 2009 by the United Nations Organization, will have the capacity of generating each year 757067 green house gas emissions reduction certificates during the next 21 years. As raw material for cogeneration plant, several palm oil mill residues will be used. One of the objectives is to improve and adequate the oxidation ponds for Palm Oil Mil Effluent (POME) as anaerobic reactors for methane gas production, which can produce organic compost as well, which can be sold as organic fertilizer in the market.

The palm oil production process consist in sterilizing the fruits, separating them, macerating them, extracting the palm oil, clarifying it, and recovering the almonds from the resulting bagasse. As consequence, 0.7 tons of residual water per ton of processed fruit are generated (Tabatabaei et al., 2010), generating environmental pollution problems due to the high organic load of the effluents. These effluents are mainly colloidal suspensions containing $95-96 \% \mathrm{H}_{2} \mathrm{O}, 0.6-0.7 \%$ oil, $4-5 \%$ of total solids from which $2-4 \%$ are suspended solids, pH 3.4 - 5.2 and high Chemical and Biological Oxygen Demand (COD and BOD) (Lam \& Lee, 2011).

Based on this, the work presented here evaluates the potential production of methane using POME as substrate, with the objective of evaluating operational conditions for anaerobic digestion like $\mathrm{pH}$ and degradation time that maximize the methane production.

\section{THEORETICAL FRAME}

Anaerobic Digestion (AD) is one of the most efficient biological processes for treating both the organic fraction of residual solids, as well as the liquid effluents. In this process, organic compounds are solubilized and hydrolyzed by the microbial action to smaller compounds and Volatile Fatty Acids (VFA), which are then degraded into methane and carbon dioxide. The final products from AD are the recovery of energy (due to methane production) and biosolids with good physicochemical characteristics to be used as soil improver or organic fertilizer (Borzacconi, López \& Viñas, 1995; Mata, Macé \& Llabrés, 2000; Yu, Samani, Hanson \& Smith, 2002).

The AD process is composed by four stages: hydrolysis, acidogenesis, acetogenesis and methanogenesis. Several environmental factors, such as $\mathrm{pH}$, nutrients availability, temperature and redox potential affect the AD (Rittmann \& McCarty, 2001). During AD process, the microbial consortium establishes a symbiotic equilibrium that generates the overall behaviour of the system, obtaining as consequence a certain conversion of organic carbon to methane (Pavlostathis \& Giraldo, 1991). The modification of this equilibrium, by altering the stages sequence during separation, generates the possibility of establishing operational conditions that optimize all of them, allowing the improvement of the overall process (Mata et al., 2000). 
The application of the AD technology depends on the design, use and development of anaerobic reactors, and is determined by operational parameters that have direct influence on the metabolism of the microorganism, the kinetic of the reactions involved in the AD and the reactor design (Sharma, Unni \& Singh, 1999). In order to improve the reaction velocity per unit of reactor volume, different reactor configurations have been tested, differing mainly in the immobilization and retention way for the microorganisms. The immobilization of biomass increases the system stability and the resistance to toxics action.

Depending on the fat, carbohydrate and protein content of the different substrates used for $\mathrm{AD}$, the methane fraction contained in the biogas obtained varied between 50 to $75 \%$. The composition of the biomass or substrate used determines the amount and final composition of the biogas produced. In general, fats and oils have a higher biogas yield (measured as $\mathrm{m}^{3} /$ ton VS), with an average methane content. Proteins have a comparative lower biogas yield, but with higher methane content. In the case of carbohydrates, they have an average yield and productivity of biogas, but with lower methane content. The concentration of solids is of importance for the biological process, for mixing effects and handling inside the reactor, as well as for the feeding system in the plant.

The different technologies and commercial systems for AD existent and emergent at industrial scale used in several countries like Japan, Switzerland, Spain, Austria, Germany, France, China, Italy and Belgium, present a biogas production between 0.10 to $0.15 \mathrm{~m}^{3} /$ $\mathrm{kg}$ of wet residue, while containing 50 to $70 \%$ methane in volume (Nichols, 2004).

\section{MATERIALS AND METHODS}

\section{Physicochemical Characterization of Substrate and Inoculums}

The wastewater (POME) used for the experiments was collected from a palm oil mill industry (San Alberto, Colombia).The physicochemical characterization of the substrate included $\mathrm{pH}$, Total and Volatile Solids (TS, VS), Total and Volatile Suspended Solids (TSS, VSS), Volatile Fatty Acids (VFA), COD, BOD 5 , Phenols, Fat and Oils content measurements. These analytics were carried out under American Public Health Association (APHA) standards (APHA, 1995).

Two different inoculums were used for the experiments. The first one (called PP inoculum) corresponded to a mixture composed by an anaerobic sludge coming from the municipal Wastewater Treatment Plant (WWTP) (Floridablanca, Colombia), and pig manure obtained from a pig processing plant (Los Santos, Colombia), in a proportion 1:1 (v/v) (Castillo, Cristancho \& Arellano, 2006). The second one (called LP inoculum) corresponded to the anaerobic sludge coming from the oxidation ponds from the same palm oil mill industry that provided the substrate.

The physicochemical characterization of the inoculums included $\mathrm{pH}$, TS and VS content, TSS and VSS content, VFA and alkalinity (Alk). These analytics were carried out under APHA standards (APHA, 1995).

The different inoculums were also evaluated in order to determine the Specific Metanogenic Activity (SMA) which is the own capacity of the inoculums to produce methane (Díaz, Espitia \& Molina, 2002). The experiments were carried out in $500 \mathrm{~mL}$ reactors. To each reactor, an inoculum volume equivalent to a concentration of $1.5 \mathrm{~g} / \mathrm{L} \mathrm{VSS}$, and a mineral balch medium were added until reaching $300 \mathrm{~mL}$ operation volume. The experiments were carried out by triplicates during 15 days at $37 \pm 2{ }^{\circ} \mathrm{C}$ incubation temperature. The biogas volume produced was quantified by alkaline displacement method using a Mariotte's bottle filled with $\mathrm{NaOH}$ $0.1 \mathrm{~N}$ solution for $\mathrm{CO}_{2}$ retention (Díaz et al., 2002). The SMA was expressed in $\mathrm{g}$ COD/g VSS* day.

\section{pH Influence on Biogas Production}

To quantify the $\mathrm{pH}$ influence in the AD process, the biogas production was evaluated using POME as substrate, at an Inoculum to Substrate Ratio (ISR) 0.5 $\mathrm{g}$ VS inoculum/g VS substrate at two differents $\mathrm{pH}$ : 4.8 and 7. The $\mathrm{pH} 4.8$ corresponded to the original $\mathrm{pH}$ from POME and the $\mathrm{pH} 7$ was reached by neutraliza- 
tion of the reactor content by adding $\mathrm{NaOH} 5 \mathrm{~N}$ every two days in anaerobic conditions. Two blank samples were prepared by adding the same inoculum quantity used in the experiment and completing the volume with distilled water. The experiments were carried out using $500 \mathrm{~mL}$ batch reactors with $300 \mathrm{~mL}$ operation volume by triplicate. Methane production was evaluated during 30 days at $37 \pm 2{ }^{\circ} \mathrm{C}$, measuring the volume of methane produced by the alkaline displacement method (Díaz et al., 2002). The final volume of methane produced by the substrate was determined by subtracting the methane produced by the blank sample. The methane accumulated yield $\left(Y_{p / s}\right)$ during the retention time is expressed in $\mathrm{m}^{3} \mathrm{CH}_{4} / \mathrm{kg}$ VS of substrate.

\section{Inoculum to Substrate Ratio (ISR) Influence on Biogas Production}

To evaluate the ISR influence on biogas production three different ISR levels were evaluated: 1, 1.5 and $2 \mathrm{~g}$ VS inoculum/g VS substrate. $500 \mathrm{~mL}$ bioreactors with a $300 \mathrm{~mL}$ operation volume were used for the experiments. The inoculum and substrate concentrations were varied in order to maintain the operation volume constant. The blank samples were prepared by adding the amount of inoculum corresponding to each ISR experiment, and completing the volume by adding distilled water to the reactor. Both biorreactors (test and blank) were incubated at $37 \pm 2^{\circ} \mathrm{C}$ during 20 days. The experiments were carried out by triplicate. In order to obtain the final methane volume produced by the substrate, the methane volume produced by the blank was subtracted. Several operational parameters were measured during the experiments, like VFA, VS, COD content and $\mathrm{pH}$ by destructive sample every 4 days. The methane volume obtained in the experiments was measured by the alkaline displacement method (Díaz et al., 2002).

The maximal methane accumulated yield $\left(Y_{p / s}\right)$ during the retention time is expressed in $\mathrm{m}^{3} \mathrm{CH}_{4} / \mathrm{kg}$ VS substrate, and it was calculated dividing the methane accumulated during the whole AD time at standard pressure and temperature conditions, by the amount of substrate added (g VS) (Raposo, Banks, Siegert \& Borja, 2006). The accumulated methane productivity $\left(Q_{p}\right)$ was also determined in $\mathrm{mL} \mathrm{CH}_{4} /$ day.

\section{RESULTS AND DISCUSSION}

\section{Physicochemical Characterization of the Substrate (POME)}

Table 1 presents the physicochemical characterization of POME wastewater. As it can be observed, it presents a high solids content and COD that makes it an appropriate substrate for biogas production. This wastewater presents acid $\mathrm{pH}$ (4.8), and for this reason, it is convenient to evaluate if $\mathrm{AD}$ at this $\mathrm{pH}$ is possible, due to previous research that indicated optimal $\mathrm{pH}$ values between 6.8-7.2 (Díaz et al., 2002). The other parameter values are in the range reported by previous authors (Chan, Chong \& Law, 2010; Mustapha, Ashhuby, Rashid \& Azni 2003; Poh \& Chong, 2009).

Table 1. Physicochemical characterization of POME substrate.

\begin{tabular}{|cc|}
\hline Parameter & Value \\
\hline $\mathrm{pH}$ & 4.8 \\
\hline $\mathrm{TS}(\mathrm{mg} / \mathrm{L})$ & $48000 \pm 492.5$ \\
\hline $\mathrm{VS}(\mathrm{mg} / \mathrm{L})$ & $10100 \pm 92.5$ \\
\hline $\mathrm{TSS}(\mathrm{mg} / \mathrm{L})$ & $34000 \pm 175$ \\
\hline $\mathrm{VSS}(\mathrm{mg} / \mathrm{L})$ & $6200 \pm 25$ \\
\hline $\mathrm{VFA}(\mathrm{mg} / \mathrm{L})$ & $6700 \pm 9.34$ \\
\hline $\mathrm{COD}(\mathrm{mg} / \mathrm{L})$ & $72800 \pm 2.57$ \\
\hline BOD $(\mathrm{mg} / \mathrm{L})$ & $24000 \pm 10 \%$ \\
\hline Fats and oils $(\mathrm{mg} / \mathrm{L})$ & $90 \pm 10 \%$ \\
\hline Phenols $(\mathrm{mg} / \mathrm{L})$ & $4 \pm 10 \%$ \\
\hline
\end{tabular}

\section{Physicochemical Characterization of the Inoculums}

Table 2 shows the physicochemical characterization of both inoculums used in the experiments. The inoculum composed by WWTP anaerobic sludge and pig manure (PP) $(1: 1 \mathrm{v} / \mathrm{v})$ presents a $\mathrm{pH}$ higher than 7 giving to the reactor an increment in this value, which probably will favour the AD process. In contrast, sludge from palm oil mill oxidation pond (LP) has a more acidic $\mathrm{pH}$ and a semisolid appearance; therefore, the VFA and Alkaline content could not be measured. 
PP sludge presents a higher content of Methanogenic Acetoclastic Bacteria, which are the main microorganisms capable of generating $2 / 3$ of methane produced, being the main responsible of the anaerobic degradation of organic matter (Castro, 2012; Quintero, 2011).

Table 2. Physicochemical characterization of inoculums.

\begin{tabular}{ccc}
\hline Parameter & PP & LP \\
\hline $\mathrm{pH}$ & 7.6 & 6.3 \\
\hline TS & $65400 \pm 535(\mathrm{mg} / \mathrm{L})$ & $29.2 \pm 0.57(\% \mathrm{w} / \mathrm{w})$ \\
\hline VS & $28700 \pm 275(\mathrm{mg} / \mathrm{L})$ & $23.5 \pm 0.43(\% \mathrm{w} / \mathrm{w})$ \\
\hline TSS & $74000 \pm 300(\mathrm{mg} / \mathrm{L})$ & $90600 \pm 68.4(\mathrm{mg} / \mathrm{L})$ \\
\hline VSS & $32200 \pm 950(\mathrm{mg} / \mathrm{L})$ & $27000 \pm 89.7(\mathrm{mg} / \mathrm{L})$ \\
\hline VFA & $1200 \pm 16.5(\mathrm{mg} / \mathrm{L})$ & N.A \\
\hline Alk & $3400 \pm 25.6(\mathrm{mg} / \mathrm{L})$ & N.A \\
\hline
\end{tabular}

\section{Evaluation of Specific Methanogenic Activity (SMA)}

The parameters used in the calculation of SMA are presented in Figure 1 and Table 3. According to the results of SMA obtained, PP inoculum presented 0.113 $\mathrm{g} \mathrm{COD} / \mathrm{g} \mathrm{VSS} *$ day, which demonstrates that it contains higher amount of methanogenic microorganisms when compared to LP. The values found are in the range reported by Field (1987), who measured different parameters for different inoculums types, reporting a SMA range between 0.02-0.2 g COD/g VSS*day.

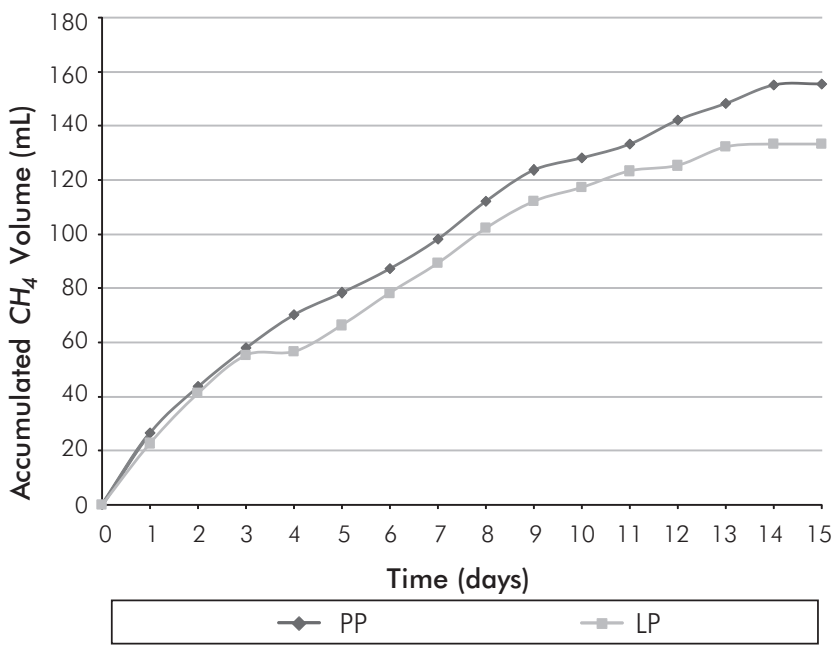

Figure 1. Kinetics of accumulated $\mathrm{CH}_{4}$ production $(\mathrm{mL})$ for each inoculum used. Initial solids concentration $1.5 \mathrm{~g} \mathrm{VSS} / \mathrm{L} \mathrm{pH}=7 \mathrm{~T}=37 \pm 2^{\circ} \mathrm{C}$.
Table 3. Evaluation of SMA for both inoculums.

\begin{tabular}{|cc|}
\hline Inoculum & SMA (g COD/g VSS*day) \\
\hline$P P$ & 0.113 \\
\hline$L P$ & 0.086 \\
\hline
\end{tabular}

\section{pH Influence on Biogas Production}

Figure 2 shows the kinetics of methane production for both different inoculums using POME as substrate. At $\mathrm{pH} 7$ the accumulated methane volume was $778 \mathrm{~mL}$ for PP, and $786 \mathrm{~mL}$ for LP inoculum. On the other side, at $\mathrm{pH} 4.8$ the accumulated methane volume was 647 $\mathrm{mL}$ for PP and $487 \mathrm{~mL}$ for LP inoculum. These results indicate that after neutralization at the beginning of the experimentation time, microorganisms adapted better to the medium, improving the starting up of the AD process, which consequently generates higher accumulated methane volume.

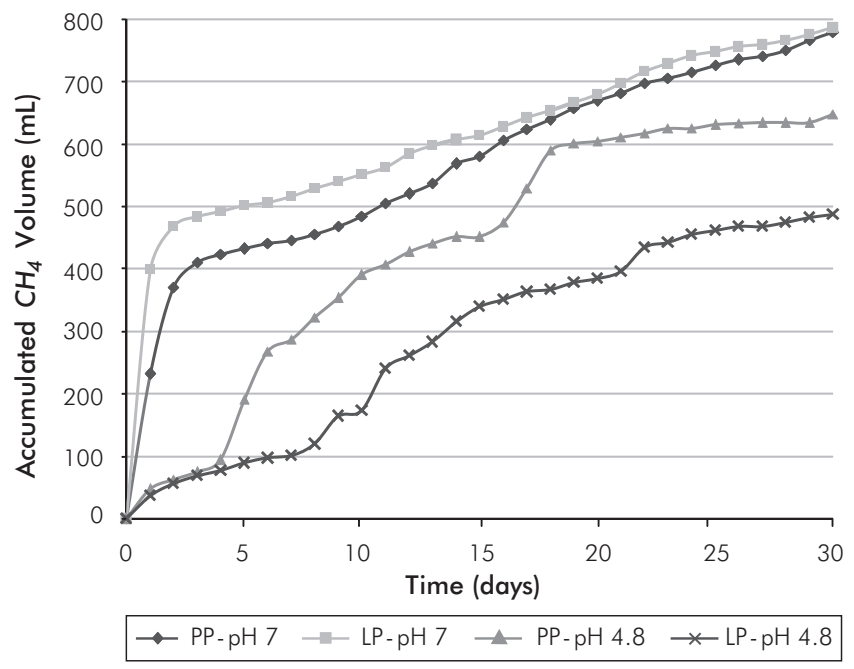

Figure 2. Kinetics of accumulated $\mathrm{CH}_{4}$ production $(\mathrm{mL})$ for both inoculums PP and $\mathrm{LP}$ at initial $\mathrm{pH} 4.8$ and $7 . \mathrm{ISR}=0.5 \mathrm{~T}=37 \pm 2^{\circ} \mathrm{C}$

Previous studies have demonstrated that AD at neutral $\mathrm{pH}$ increases the methane production because it favours the microorganism's growth, as well as avoids VFA accumulation which negatively affects the system stability (Poh \& Chong, 2009; Chen, Cheng \& Creamer, 2008). However, at the end of the AD process, for the experiments using PP inoculums, the difference in the final accumulated methane volume (at $\mathrm{pH} 4.8$ and $\mathrm{pH}$ 7) is lower than the final accumulated methane volume obtained when using LP inoculum. That indicates that 
after the starting up, the $\mathrm{AD}$ process progresses at the same velocity in both cases. This can be attributed to the fact that PP inoculum has neutral $\mathrm{pH}$ (7.6), which contributes to the own microorganism's adaptability to the medium.

On the other side, when using LP as inoculum, it presents a higher difference in methane production at the two different $\mathrm{pH}$ used in the experiments. This is because LP inoculum is acidic ( $\mathrm{pH}$ 6.3) in comparison to PP inoculum, which is not enough to neutralize the $\mathrm{pH}$ of the system, and consequently the AD system is unstable, producing lower amount of methane. Due to the difficulties in controlling the $\mathrm{pH}$ during the development of the $\mathrm{AD}$ process (in which the neutralization is necessary every two days) it was decided to continue working with both inoculums at the original $\mathrm{pH}$ of residual wastewater ( $\mathrm{pH} 4.8$ ), avoiding the continuous neutralization of the system inside the reactors.

\section{ISR Influence on Biogas Production}

The influence of ISR was evaluated on AD of POME in batch experiments. The different parameters affecting the $\mathrm{AD}$ process such as $\mathrm{pH}$ and VFA accumulation were measured. Due to this, they indicated acidification inside the reactor. The amount of inoculum and substrate to be added in each reactor were also evaluated.

Table 4 presents the accumulated methane volume and $\mathrm{Q}_{\mathrm{p}}$ for both inoculums at the different ISR studied. The results showed that the higher methane production was obtained at ISR 2 using PP as inoculum, obtaining 2740 $\mathrm{mL}$ of accumulated methane volume. This demonstrates that at higher organic load of inoculum added to the reactor, the methane production increases, and consequently the volumetric productivity of methane per day.
From the data obtained, the percentage of VS removal was calculated, and it was related to the maximal accumulated methane volume obtained. As it can be expected for a typical $\mathrm{AD}$ process, while the VS concentration decreases, the accumulated methane volume production increases. This can be attributed to the operation time in which the organic matter degrades, which is used by the microorganisms for producing methane. As it can be observed, the \% VS removal was in the range between $13.42-55.52 \%$ corresponding to LP at ISR 1 and PP at ISR 2, respectively. These data are concordant with the methane production results. The percentage of VS removal for PP at ISR 2 was higher than the reported by Forster, Pérez and Romero (2008), who studied the influence of solids in the AD process using urban solid residues as substrate, finding a value of $49.7 \% \mathrm{VS}$ removal.

Figure 3 shows the kinetics of methane production at each ISR studied for both inoculums (PP and LP). The highest yield $\left(Y_{p / s}\right)$ was obtained at ISR 2 using $\mathrm{PP}$ as inoculum, obtaining $0.343 \mathrm{~m}^{3} \mathrm{CH}_{4} / \mathrm{kg}$ VS. This value was lower in comparison with that obtained with the same ISR but using fique pulp as substrate and a mixture between rumen fluid and pig manure as inoculum, reaching a maximal yield of $0.446 \mathrm{~m}^{3} \mathrm{CH}_{4} / \mathrm{kg} \mathrm{VS}$ (Quintero, 2011).

In the literature it was found that there is a linear relationship between methane yield and the ISR (Chen et al., 2008; Chaiprapat \& Laklam, 2011). Recent studies on the effect of ISR on AD of algae have demonstrated that methane yield decreased from $0.140 \mathrm{~m}^{3} \mathrm{CH}_{4} / \mathrm{kg} \mathrm{VS}$ to $0.094 \mathrm{~m}^{3} \mathrm{CH}_{4} / \mathrm{kg}$ VS when the ISR was decreased from 2 to 0.5 (Dinsdale, Premier \& Hawkes, 2000).

Table 4. $Q_{p}$, accumulated methane volume and \% VS removal for the different ISR studied.

\begin{tabular}{|c|c|c|c|c|c|c|}
\hline \multicolumn{3}{|c|}{ Methane Accumulated Volume (mL) } & \multicolumn{2}{|c|}{$\mathrm{Q}_{\mathrm{p}}\left(\mathrm{mL} \mathrm{CH} \mathrm{CH}_{4} /\right.$ day $)$} & \multicolumn{2}{|c|}{ \% VS Removal } \\
\hline ISR & PP & LP & PP & LP & PP & LP \\
\hline 1 & $1360 \pm 30$ & $890 \pm 40$ & $68 \pm 1.5$ & $44.5 \pm 2$ & 35.81 & 13.42 \\
\hline 1.5 & $1922 \pm 28$ & $947 \pm 17.5$ & $96.1 \pm 1.4$ & $47.4 \pm 0.88$ & 51.82 & 31.70 \\
\hline 2 & $2740 \pm 40$ & $1411 \pm 9$ & $137 \pm 2$ & $70.5 \pm 0.45$ & 55.52 & 44.60 \\
\hline
\end{tabular}




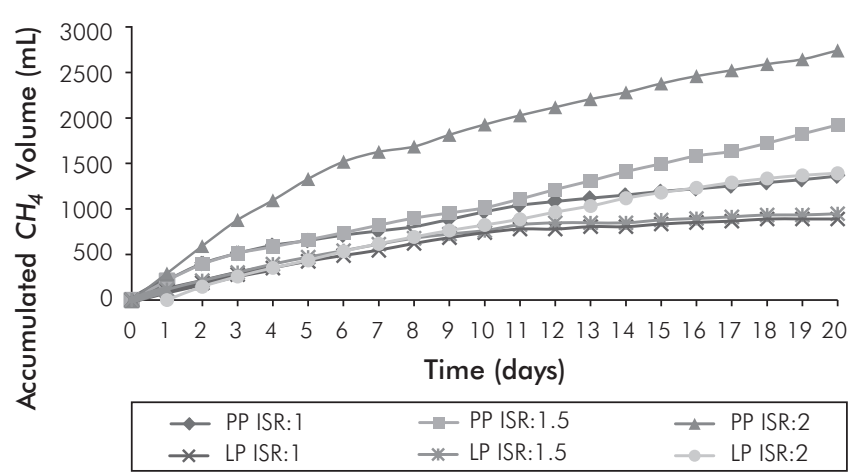

Figure 3. Kinetics of methane production at different ISR $T=37 \pm 2^{\circ} \mathrm{C}$ Initial $\mathrm{pH}=4.8$.

The $\mathrm{pH}$ is one of the most important parameters in the methane production process, because microorganisms are $\mathrm{pH}$-dependent in order to correctly develop its metabolic activity (Chaiprapat \& Laklam, 2011). It can be observed -in Figure 4- the $\mathrm{pH}$ evolution at different ISR in the experiments using both inoculums. Lower $\mathrm{pH}$ values during experiments were observed for the reactors inoculated with LP, caused by the lower initial $\mathrm{pH}$ of this inoculum. Higher $\mathrm{pH}$ values were observed in those reactors inoculated with PP.

During the whole degradation time, the experiments using PP inoculum at ISR 2 showed appropriate $\mathrm{pH}$ values, demonstrating that at neutral conditions the methane production increases, being coincident with the optimal range of $\mathrm{pH}$ 6.8-7.2 reported by previous studies (Lam \& Lee, 2011; de La Rubia, Raposo, Rincón \& Borja, 2009).

In Figure 5, the behaviour of VFA/Alk ratio during the experiments can be observed. In the case that the reactors were inoculated with LP at ISR 1 and 1.5, they presented acidification due to the fact that VFA concentration was in a range between $8000-8500 \mathrm{mg} / \mathrm{L}$, showing a decrease in methane production. According to the literature, VFA concentration higher than $8000 \mathrm{mg} / \mathrm{L}$ causes reactor acidification and inhibits the methane production (Quintero, 2011).

$\mathrm{pH}$ stability during experiments using PP at ISR 1.5 and 2 can be attributed to the buffer capacity of the inoculum itself (Poh \& Chong, 2009), represented by the Alk values between 10000 - $15000 \mathrm{mg} \mathrm{CaCO}_{3} / \mathrm{L}$ for

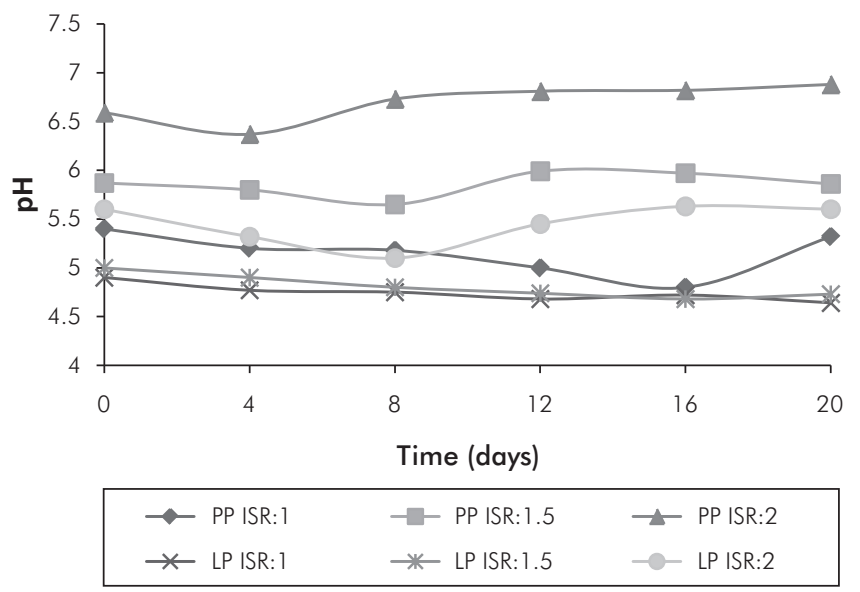

Figure 4. Evolution of $\mathrm{pH}$ at the different ISR studied using LP and $\mathrm{PP}$ inoculums. $\mathrm{T}=37 \pm 2^{\circ} \mathrm{C}$, Initial $\mathrm{pH}=4.8$.

PP inoculum at ISR 2. Apparently, the media and/or the microorganisms that are present in this inoculum exert a buffer effect over the bioprocess (Dinsdale et al., 2000), as was previously evidenced by the $\mathrm{pH}$ influence evaluation.

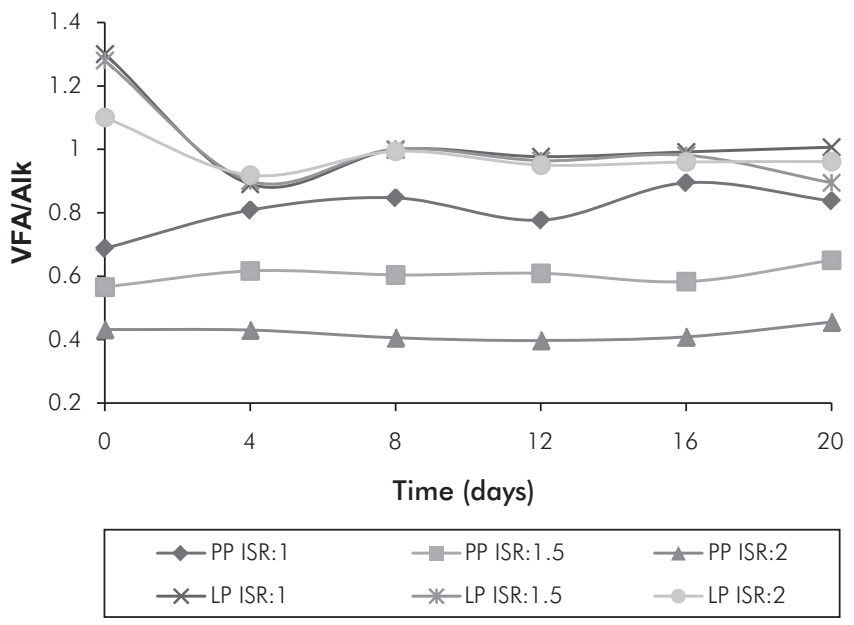

Figure 5. Evolution of VFA/Alk ratio at $\mathrm{T}=37 \pm 2^{\circ} \mathrm{C}$ Initial $\mathrm{pH}=4.8$ for both inoculums.

For an optimal operation of the $\mathrm{AD}$ process, the range for the VFA/Alk ratio should be between 0.1 - 0.4. These values are adequate for this type of systems in order to avoid acidification or inhibition during the AD process (Zeng, Yuan, Shi \& Qiu, 2010; de La Rubia et al., 2009). The VFA/Alk ratio presented a value near to 0.4 for PP at ISR 2, being the lowest of this process. 
When the values of VFA/Alk ratio are lower than 0.4 , the $\mathrm{AD}$ is favoured, while at values higher than 0.8 the process fails, decreasing the methane production. This was evidenced by the lower methane production for those reactors inoculated with LP, because the VFA/Alk ratio was between $0.8-1.4$.

Figure 6 shows the evolution of the accumulated COD (\%) removal during the experimentation time, varying between $9 \%$ for LP at ISR 1 and $47 \%$ for PP at ISR 2. These values are in the range between $27-83 \%$ COD removal reported by (Chan et al., 2010). It can be observed that while the accumulated methane volume increased, COD (\%) removal also increased, showing a direct relationship between these two factors.

While ISR increases, methane production and COD and VS removal increase. This fact can be explained because at higher ISR, a higher concentration of microorganisms capable of degrading the organic matter emerge, being favoured also by the higher $\mathrm{pH}$ value (near 7) present in the system during the experimentation time.

Finally, for the anaerobic degradation process of POME it was found that the higher methane production was reached using a mixture $1: 1 \mathrm{v} / \mathrm{v}$ WWTP anaerobic sludge: pig manure (PP) as inoculums at a ratio $2 \mathrm{~g} \mathrm{VS}$ inoculum per gram of VS substrate. At these conditions, it was possible to obtain $2740 \mathrm{~mL}$ of accumulated methane volume $\left(0.343 \mathrm{~m}^{3} \mathrm{CH}_{4} / \mathrm{kg} \mathrm{VS}\right)$, without any $\mathrm{pH}$ neutralization step.

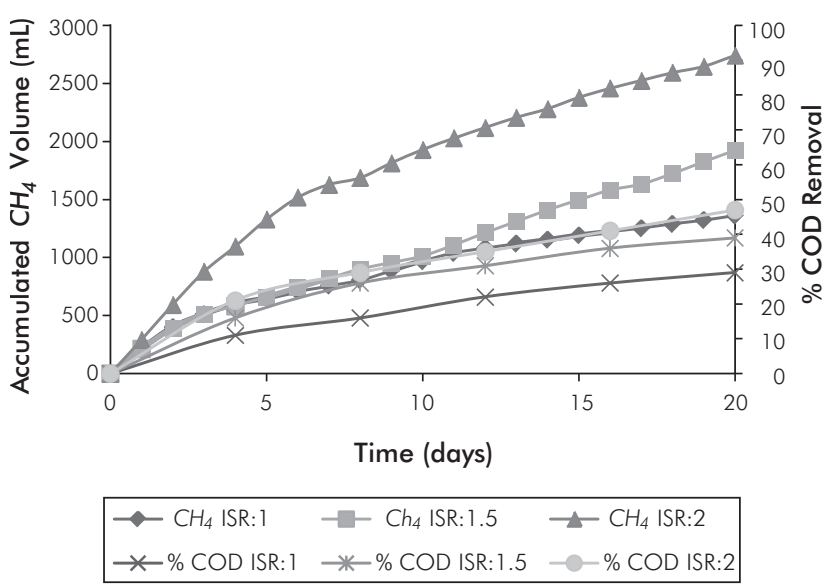

(a)

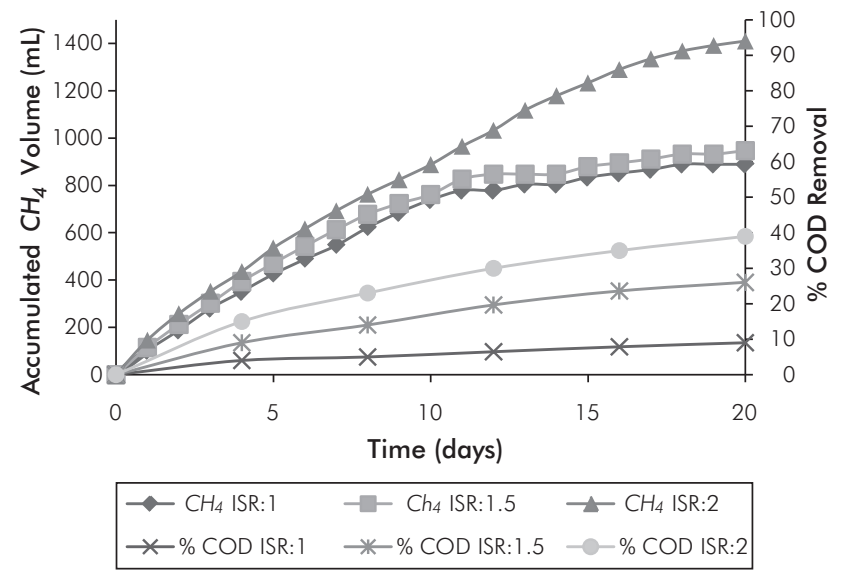

(b)

Figure 6. $\mathrm{COD}(\%)$ removal in comparison with accumulated $\mathrm{CH}_{4}$ volume. $\mathrm{T}=37 \pm 2^{\circ} \mathrm{C}$ Initial pH 4.8 a) PP b) LP.

\section{CONCLUSIONS}

- This research have demonstrated that methane production by AD using palm oil mill effluent as substrate, and other residues as inoculums, is viable, making possible to solve pollution problems and inadequate soil uses in the environment. This process can also lead to implement a source of renewable energy available to the same industrial sector.

\section{ACKNOWLEDGEMENTS}

Authors want to acknowledge Universidad Industrial de Santander - Centro de Estudios e Investigaciones Ambientales (CEIAM) for financial resources and equipment used during this research, and to Dr. Liliana Castro for her kind collaboration during the project.

\section{REFERENCES}

APHA, WEF, AWWA(1995). Standard Methods for the Examination of Water and Wastewater, 19th ed. American Public Health Association, Washington DC. 
Borzacconi, L., López, I. \& Viñas, M. (1995). Application of anaerobic digestion to the treatment of agroindustrial effluents in Latin America. Water Sci. Technol., 32(12), 105-111.

Castillo, E., Cristancho, D. \& Arellano, V. (2006). Study of the operational conditions for anaerobic digestion of urban solid wastes, Waste Manag., 26(5), 546-556.

Castro, L. (2012). Proceso integral para la digestión anaerobia del bagazo de fique. Tesis doctoral Fac. Ingenierías Fisicoquímicas, Universidad Industrial de Santander, Bucaramanga, Colombia, 176pp.

Chaiprapat, S. \& Laklam, T. (2011). Enhancing digestion efficiency of POME in anaerobic sequencing batch reactor with ozonation pretreatment and cycle time reduction. Bioresour. Technol., 102(5), 4061-4068.

Chan,Y., Chong, M. \& Law, C. (2010). Biological treatment of anaerobically digested Palm Oil Mill Effluent (POME) using a lab-scale Sequencing Batch Reactor (SBR). J. Environ. Manag., 91(8), 1738-1746.

Chen, Y., Cheng, J. \& Creamer, K. (2008). Inhibition of anaerobic digestion process. Bioresour. Technol., 99(10), 4044-4064.

de La Rubia, M., Raposo, F., Rincón, B. \& Borja, R. (2009). Evaluation of the hydrolytic-acidogenic step of a two-stage mesophilic anaerobic digestion process of sunflower oil cake. Bioresour. Technol., 100(18), 4133-4138.

Díaz, M., Espitia, S. \& Molina, F. (2002). Digestión anaerobia: Una aproximación a la tecnología. Bogotá: Unibiblos.

Dinsdale, R., Premier, G., Hawkes, F. \& Hawkes, D. (2000). Two-stage anaerobic co-digestion of waste activated sludge and fruit/vegetable waste using inclined tubular digesters. Bioresour. Technol., 72(2), 159-168.

Field, J. (1987). Parámetros operativos del reactor de manto de lodos anaeróbicos de flujo ascendente. Curso Arranque y operación de reactores anaerobios con flujo ascendente y manto de lodos (UASB). Universidad del Valle, Cali, Colombia.

Forster, T., Pérez, M. \& Romero, L. (2008). Influences of total solid and inoculum on performance of anaerobic reactors treating food waste. Bioresour. Technol., 99(15), 6994-7002.

Lam, M. \& Lee, K. (2011). Renewable and sustainable bioenergies production from Palm Oil Mill Effluent (POME):
Win-win strategies toward better environmental protection. Biotechnol. Adv., 29(1), 124-141.

Lasso, J. \& Ramírez, J. (2011). Perspectivas generales del efecto del reúso de aguas residuales para riego en cultivos para la producción de biocombustibles en Colombia. $E l$ Hombre y la Máquina, 36: 95-105.

Mata, A., Macé, S. \& Llabrés, P. (2000). Anaerobic digestion of organic solid wastes. An overview of research achievements and perspectives. Bioresour. Technol., 74(1), 3-16.

Mustapha, S., Ashhuby, B., Rashid, M. \& Azni, I. (2003). Start-up strategy of a thermophilic upflow anaerobic filter for treating palm oil mill effluent. Trans. I Chem E., 81(4), 262-266.

Nichols, C. (2004). Overview of anaerobic digestion technologies in Europe. BioCycle, 45(1), 47-53.

Pavlostathis, S. \& Giraldo, G. (1991). Kinetics of anaerobic treatment. Water Sci. Technol., 24(8), 35-59.

Poh, P. \& Chong, M. (2009). Development of anaerobic digestion methods for Palm Oil Mill Effluent (POME) treatment. Bioresour. Technol., 100(1) 1-9.

Quintero, M. (2011). Estudio de consorcios microbianos para la producción de biogás a partir de residuos de fique. Tesis de maestría, Fac. Ingenierías Fisicoquímicas, Universidad Industrial de Santander, Bucaramanga, Colombia, 104pp.

Raposo, F., Banks, C., Siegert, I. \& Borja, R. (2006). Influence of inoculum to substrate ratio on the biochemical methane potential of maize in batch tests. Biochemistry, 41(6), 1444-1450.

Rittmann, B. \& McCarty, P. (2001). Biotecnología del medio ambiente, principios y aplicaciones, España: McGraw Hill.

Sharma, A., Unni, B. \& Singh, H. (1999). A novel fed-batch digestion system for biomethanation of plant biomasses. J. Biosci. Bioeng., 87(5), 678-682.

Tabatabaei, M., Rahim, R., Abdullah, N., Wright, A. Shirai, Y., Sakai, K., Sulaiman, A. \& Hassan, M.(2010). Importance of the methanogenic archaea populations in anaerobic wastewater treatments. Biochemistry, 45(8), 1214-1225.

Yu, H., Samani, Z., Hanson, A. \& Smith, G. (2002). Energy recovery from grass using two phase anaerobic digestion. Waste Manag., 22(1), 1-5. 
Zeng, S., Yuan, X., Shi, X. \& Qiu, Y. (2010) Effect of inocu$\mathrm{lum} /$ substrate ratio on methane yield and orthophosphate release from anaerobic digestion of microcystis. J. Hazard. Mat., 178(1-3), 89-93.

\section{AUTHORS}

\section{Debora-Alcida Nabarlatz}

Affiliation: Universidad Industrial de Santander.

Ing. Química, Universidad Nacional de Mar del Plata, Argentina.

Ph. D. Ing. Química y de Procesos, Universitat Rovira i Virgili,

España.

e-mail: dnabarla@uis.edu.co

\section{Ligia-Patricia Arenas-Beltrán}

Affiliation: Universidad Industrial de Santander. Ing. Química, Universidad Industrial de Santander. M. Sc. Ing. Química, Universidad Industrial de Santander. e-mail: 1parenas@gmail.com

\section{Diana-Milena Herrera-Soracá}

Affiliation: Universidad Industrial de Santander. Ing. Química, Universidad Industrial de Santander. e-mail: chanah123@hotmail.com

\section{Diana-Andrea Niño-Bonilla}

Affiliation: Universidad Industrial de Santander. Ing. Química, Universidad Industrial de Santander. e-mail: dianis1411@hotmail.com 
